\title{
ANALISIS TATAR PERILAKU SEBAGAI LANGKAH AWAL UNTUK MEMBANGUN DESAIN INTERIOR SARANA PENDIDIKAN ANAK AUTIS
}

\author{
Kharista Astrini Sakya ${ }^{1}$, Imam Santosa ${ }^{2}$, Andar Bagus ${ }^{3}$, Indun Lestari ${ }^{4}$ \\ 1,2,3 Institut Teknologi Bandung \\ Jl. Ganesha No. 10. Bandung. Jawa Barat \\ ${ }^{4}$ Dwipayana Biro Konsultasi Psikologi \\ Jl. Panaitan No. 15. Bandung. Jawa Barat \\ ${ }^{1}$ kharistaastrinisakya@fsrd.itb.ac.id, ${ }^{2}$ imamz@fsrd.itb.ac.id, ${ }^{3}$ andarbugs@fsrd.itb.ac.id
}

\begin{abstract}
Empowering interior design to lead to better development can be done from small things such as paying attention to the means of education for autistic children. Interior designers can play a role in building educational facilities in accordance with the behavior of children with autism. Autistic behavior can be caused by not being able to process information properly from the stimuli of the physical environment (space) around it. The purpose of this study is to analyze the behavior of children with autism as a first step if they want to build an interior design for children with autism education in accordance with the behavior, so it is expected that if they know the behavior in the room, then the interior designer can design the educational facilities according to their needs and will maximum. The limitation of this study is only to analyze the behavior of autistic children in the therapy room according to the researcher's perspective as an interior designer. The method used is observation of children's behavior in the room during the therapy process, using video recorders. Analysis was carried out by anova statistical test. The results showed that there were differences in the number of children's behavior in the room when with the therapist and when alone. Before the therapy process takes place, the child will carry out the adaptation phase, showing curiosity whether the space / object makes the child comfortable / uncomfortable. In addition, children have the same behavior that is easily distracted with interior elements.
\end{abstract}

Keyword : behaviour, interior design, autism children

\begin{abstract}
Abstrak
Memberdayakan desain interior untuk menuju pembangunan yang lebih baik dapat dilakukan dari hal kecil seperti memperhatikan sarana pendidikan anak autis. Desainer interior dapat berperan dalam membangun sarana pendidikan yang sesuai dengan tatar perilaku anak autis. Perilaku autis dapat disebabkan karena tidak dapat mengolah informasi secara baik dari stimuli lingkungan fisik (ruang) yang ada di sekitarnya. Tujuan dari penelitian ini adalah untuk menganalisis tatar perilaku anak autis sebagai langkah awal jika ingin membangun desain interior sarana pendidikan anak autis yang sesuai dengan perilaku, sehingga diharapkan jika telah mengetahui perilaku di dalam ruang, maka desainer interior dapat mendesain sarana pendidikan tersebut sesuai kebutuhan dan akan maksimal. Batasan penelitian ini hanya menganalisis tatar perilaku anak autis di dalam ruang terapi saja menurut sudut pandang peneliti sebagai desainer interior. Metode yang digunakan adalah observasi tatar perilaku anak di dalam ruang ketika proses terapi, menggunakan video perekam. Analisis dilakukan dengan uji statistik anova. Hasil penelitian menunjukkan bahwa terdapat perbedaan jumlah perilaku anak di dalam ruang ketika bersama terapis dan ketika sendirian. Sebelum proses terapi berlangsung, anak akan melakukan fase adaptasi, menunjukkan keingintahuan apakah ruang / objek tersebut membuat anak nyaman / tidak. Selain itu, anak memiliki perilaku yang sama yaitu mudah terdistraksi dengan elemen interior.
\end{abstract}

Kata kunci : tatar perilaku, desain interior, anak autis

TERAKREDITASI : 36/E/KPT/2019

Tesa Arsitektur Volume 18| Nomor 1 | 2020 


\section{PENDAHULUAN}

Memberdayakan desain interior untuk menuju pembangunan yang lebih baik dapat dilakukan dari hal kecil seperti memperhatikan sarana pendidikan anak autis. Hingga saat ini belum pernah dilakukan penelitian mengenai prevalensi anak autis (Handojo, 2003) sehingga belum ada data yang akurat mengenai data anak autis. Autis terjadi 5 dari 10.000 kelahiran (Maulana, 2007). Menurut data, perbandingan di Indonesia telah mendekati 1: 160 per kelahiran. Perbandingan antara anak laki - laki dan perempuan yang mengalami gangguan autis adalah 4:1 (Budiman dalam Handojo, 2003).

Desainer interior dapat berperan dalam membangun sarana pendidikan yang sesuai dengan tatar perilaku anak autis. Perilaku autis dapat disebabkan karena tidak dapat mengolah informasi secara baik dari stimuli lingkungan fisik (ruang) yang ada di sekitarnya. Tujuan dari penelitian ini adalah untuk menganalisis tatar perilaku anak autis sebagai langkah awal jika ingin membangun desain interior sarana pendidikan anak autis yang sesuai dengan perilaku, sehingga diharapkan jika telah mengetahui perilaku di dalam ruang, maka desainer interior dapat mendesain sarana pendidikan tersebut sesuai kebutuhan dan akan maksimal. Batasan penelitian ini hanya menganalisis tatar perilaku anak autis di dalam ruang terapi saja menurut sudut pandang peneliti sebagai desainer interior karena subjek tidak dapat diminta pendapat.

\section{KAJIAN TEORI}

\section{Desain Interior}

Desain interior adalah sebuah perencanaan, penataan letak dan perancangan ruang di dalam bangunan (Ching, 1996). Tujuan dari perancangan interior adalah pengembangan fungsi, pengayaan estetis dan peningkatan psikologi ruang interior (Ching, 1996). Desain interior digunakan untuk mengefektifkan ruang interior guna mendukung segala kegiatan manusia yang dilakukan di area tersebut (Pile, 2000).

\section{Autis}

Autis berasal dari kata auto yang berarti sendiri. Autis adalah gangguan perkembangan yang kompleks, yang disebabkan oleh adanya kerusakan pada otak, sehingga mengakibatkan gangguan pada perkembangan komunikasi, perilaku, kemampuan sosialisasi, sensori, belajar dan bukan suatu penyakit mental (Peeters, 2004).

\section{Desain Interior untuk Autis}

Penelitian menjelaskan bahwa lingkungan memainkan penting peran dalam kehidupan anak-anak autis (Wildes, 2005). Memanfaatkan lingkungan fisik untuk mengakomodasi kebutuhan anakanak autis dapat meningkatkan interaksi sosial mereka (Ghaziani, 2008). Jika ada masalah desain pada arsitektural rehabilitasi autis, maka dapat merugikan dan menurunkan kemampuan anak autis untuk belajar (Jenkins, 2009).

\section{Tatar Perilaku}

Tatar perilaku (behavior setting) adalah pola perilaku manusia yang berkaitan dengan susunan lingkungan fisik (Barker dalam Laurens, 2004). Tatar perilaku berarti pula ruang aktifitas untuk memperlihatkan relasi antara lingkungan arsitektural dengan perilaku pengguna di dalamnya (Haviland dalam Laurens, 2004). Beberapa kualifikasi agar dapat disebut dengan tatar perilaku yang seimbang (Barker dalam Laurens, 2004) adalah:

1. Terdapat suatu aktivitas yang berulang, berupa suatu pola perilaku (standing pattern of behaviour).

2. Tata lingkungan (ruang terbuka / tertutup) tertentu (circumjacent milieu), milieu berkaitan dengan pola perilaku.

3. Membentuk suatu hubungan yang sama antar keduanya (synomorphy).

4. Dilakukan pada periode waktu tertentu. 
Terdapat tiga model pengamatan atau observasi dalam penelitian arsitektur dan perilaku manusia, yaitu model dengan metode place centered map dan person centered map.

\section{a. Metode Place Centered Mapping}

Pemetaan berdasarkan tempat dimana kegiatan berlangsung, bertujuan untuk mengetahui bagaimana manusia atau kelompok manusia memanfaatkan, menggunakan atau mengakomodasi perilakunya dalam suatu situasi waktu dan tempat tertentu. Perhatian dari teknik atau metoda ini adalah suatu tempat yang spesifik baik kecil ataupun besar dalam satu setting yang tetap (Haryadi, 1995).

\section{b. Metode Person Centered Mapping}

Salah satu metoda penelitian arsitektur penelitian dan perilaku adalah metode person centered mapping (Sommer, 2001). Metode ini menekankan pada pergerakan manusia pada periode waktu-waktu tertentu. Teknik ini berkaitan dengan tidak hanya satu tempat atau lokasi, akan tetapi beberapa tempat atau lokasi. Metode ini mengharuskan peneliti berhadapan dengan seseorang atau kelompok manusia yang khusus diamati. Tahapan yang harus dilakukan dalam menggunakan teknik ini adalah sebagai berikut:

a. Menentukan jenis sampel manusia yang akan diamati (aktor atau penggunaan ruang secara individu).

b. Menentukan waktu pengamatan (pagi, siang dan malam).

c. Mengamati aktivitas yang dilakukan dari masing-masing sampel pengguna.

d. Mencatat aktivitas sampel person yang diamati dalam matriks atau tabel.

Metode person centered mapping dilakukan dengan membuat alur sirkulasi sampel pengguna di area yang diamati atau di peta untuk mengetahui dari mana dan kemana orang pergi dengan mengidentifikasi arah lintasan pergerakannya.

\section{c. Metode Phsycal Traces}

Metode pengamatan terhadap jejak-jejak fisik hasilnya dapat disajikan dalam bentuk rekaman tanda-tanda yang ditinggalkan oleh kegiatan yang berlangsung sebelumnya (Sommer, 2001).

Pengukuran perilaku dapat menggunakan beberapa metode, diantaranya menghitung jumlah frekuensi, nilai, durasi, kelancaran dan ukuran respon.

\section{METODE PENELITIAN}

Metode yang digunakan adalah kualitatif dengan cara melakukan observasi tatar perilaku anak autis di dalam ruang ketika proses terapi menggunakan video perekam di salah satu rumah sakit di Kota Bandung. Analisis perilaku anak setiap periode dilakukan dengan cara pengamatan rekaman video dari langitlangit ruang selama 1 sesi terapi (20 - 45 menit, dalam keadaan ketika anak sendirian maupun ketika ada terapis) terhadap 8 anak autis kategori low function dan memiliki tingkat kemampuan imitasi rendah. Metoda penelitian arsitektur penelitian dan perilaku yang digunakan adalah metode person centered mapping (Sommer, 2001). Pengukuran perilaku dilakukan dengan cara menghitung jumlah frekuensi. Analisis dilakukan dengan uji statistik anova.

\section{HASIL PENELITIAN DAN PEMBAHASAN}

\section{Keadaan Ruang Terapi}

Observasi tatar perilaku dilakukan pada ruang terapi perilaku anak autis. Ruang yang digunakan terdiri dari 1 buah meja, 1 buah kursi, 1 buah jam, jendela dalam keadaan terbuka, pintu dalam keadaan tertutup, dinding dan lantai menggunakan matras busa berwarna hijau, suhu ruang normal menggunakan pendingin udara antara $20^{\circ}-25^{\circ} \mathrm{C}$. Terapis akan melakukan instruksi terapi perilaku yang sudah biasa dilakukan. Terapis akan duduk di lantai, berhadapan dengan anak yang duduk di kursi.

Tesa Arsitektur Volume 18| Nomor 1 | 2020 


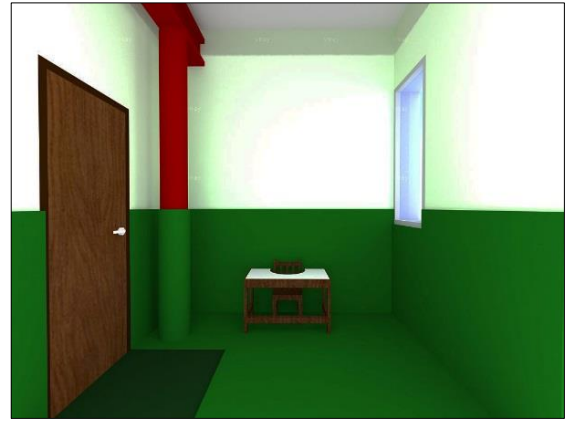

Gambar 1. Layout Ruang Terapi

(Sumber: Kharista, 2018)

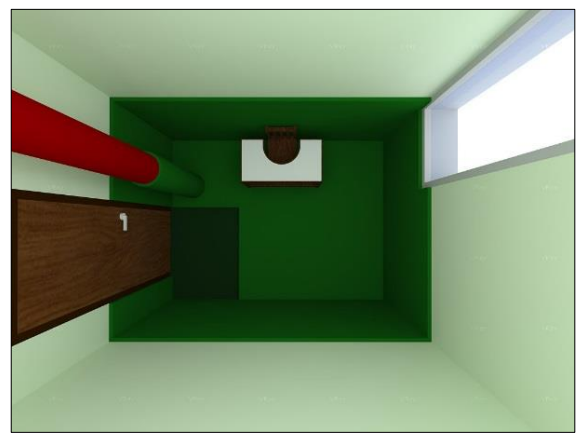

Gambar 2. Tampak Atas Ruang Terapi

(Sumber: Kharista, 2018)

\section{Pola Sirkulasi Anak ketika Masuk Ruang}

Pertama - tama, anak akan masuk ruang terapi bersama dengan terapis. Lalu anak akan mengeksplorasi ruang / berkeliling. Ada yang memegang dinding, menepuk, melihat jendela, dll. Ini dapat diartikan pula bahwa anak sedang mencaritahu apakah ruang ini nyaman / aman untuk dirinya. Pola sirkulasi dapat dilihat pada denah gambar.

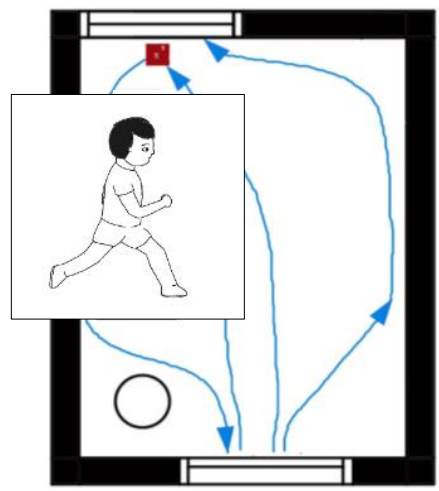

Gambar 3. Denah Sirkulasi Ruang Terapi (Sumber: Kharista, 2018)
Tatar Perilaku Anak setiap Periode (0-40 menit) dan Analisis

Analisis perilaku anak setiap periode dilakukan dengan cara pengamatan rekaman video dari langit-langit ruang selama 1 sesi terapi terhadap 8 anak autis kategori low function dan memiliki tingkat kemampuan imitasi rendah.

Hasil pengamatan jenis perilaku diantaranya adalah anak melihat jendela, berceloteh, melihat benda yang dipegang terapis, melihat pintu, memukul meja, menyender ke dinding belakang, melihat ujung kiri depan, berteriak, mendengkur, melihat ujung kanan depan, melihat ke depan, memegang tangan terapis, tertawa, berusaha keluar dari meja, menaikkan kaki ke kursi, duduk di lantai, membuka dan menutup kotak kartu, mondar - mandir, dll.
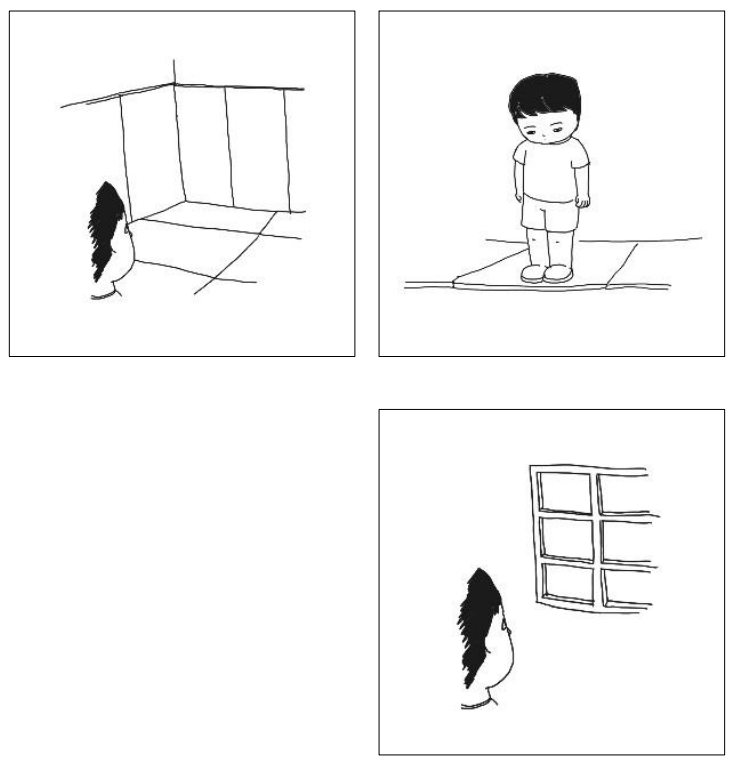

Gambar 4. Perilaku Anak Autis

(Sumber: Kharista, 2018)

1. Analisis tatar perilaku anak ke - 1 setiap periode ( 0 - 25 menit) ketika proses terapi dijelaskan pada Gambar 5 dan periode (25 - 45 menit) dijelaskan pada Gambar 6. 


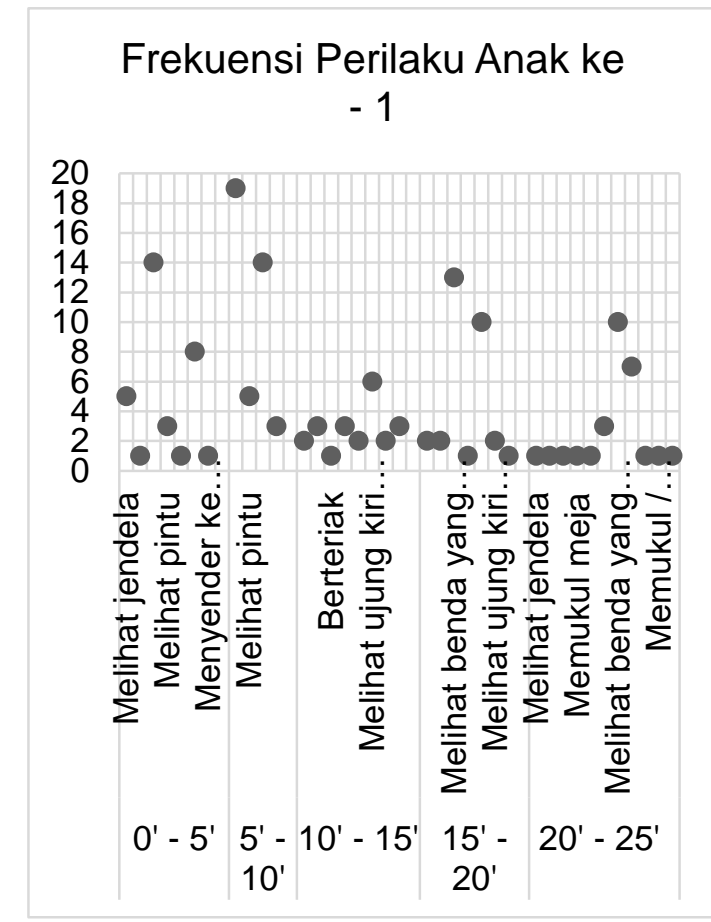

Gambar 5. Grafik frekuensi perilaku anak ke - 1 a

(Sumber: Kharista, 2018)

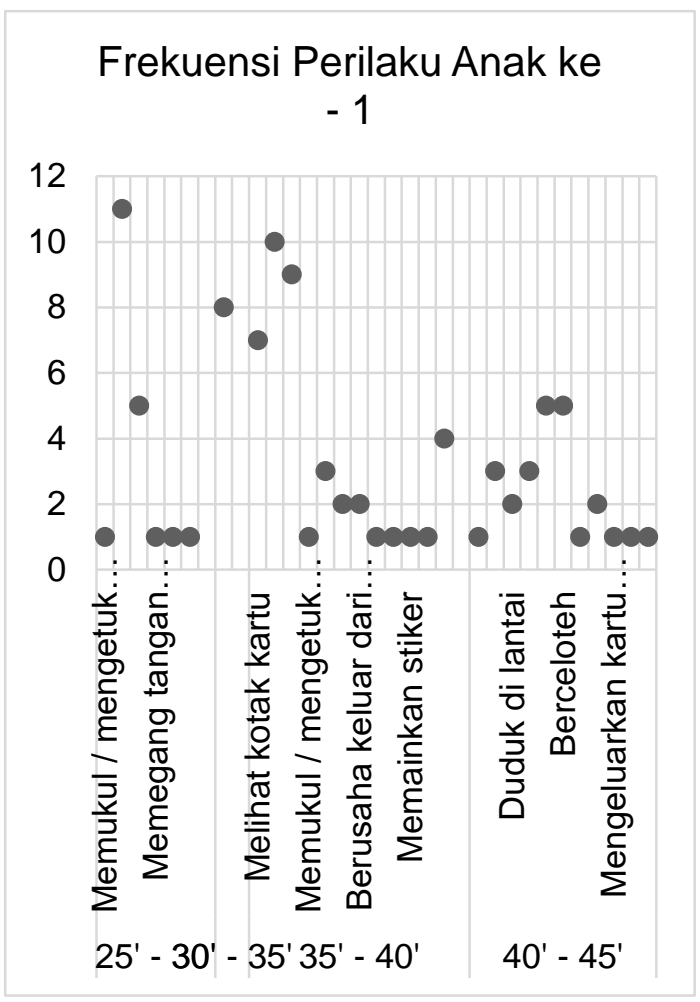

Gambar 6. Grafik frekuensi perilaku anak ke - 1 b

(Sumber: Kharista, 2018)
Frekuensi perilaku anak ke - 1 paling tinggi adalah melihat benda di tangan terapis sejumlah 19 kali pada periode 5 10 menit. Interaksi dengan elemen interior paling banyak adalah melihat jam sejumlah 18 kali dalam total waktu 45 menit. Sementara, jenis perilaku paling banyak dilakukan pada periode $35-40$ menit yaitu sejumlah 12 jenis. Jenis perilaku paling sedikit dilakukan pada periode $30-35$ menit yaitu sejumlah 1 jenis.

2. Analisis tatar perilaku anak ke - 2 setiap periode (0 - 25 menit) ketika proses terapi dijelaskan pada Gambar 7 dan periode (25 - 45 menit) dijelaskan pada Gambar 8.

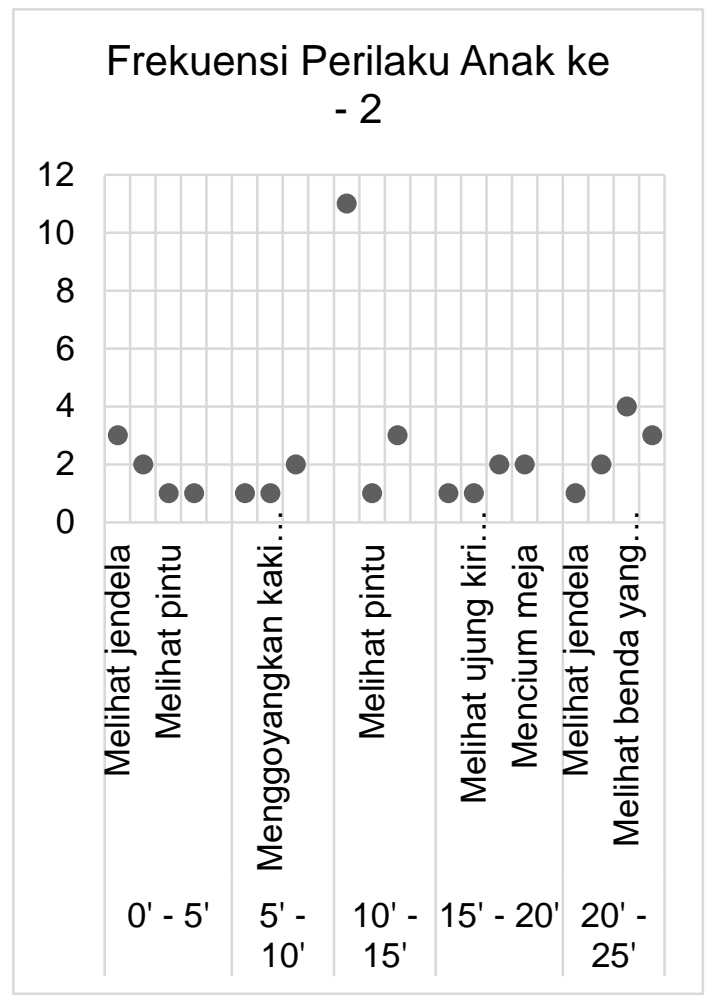

Gambar 7. Grafik frekuensi perilaku anak ke - 2 a

(Sumber: Kharista, 2018) 


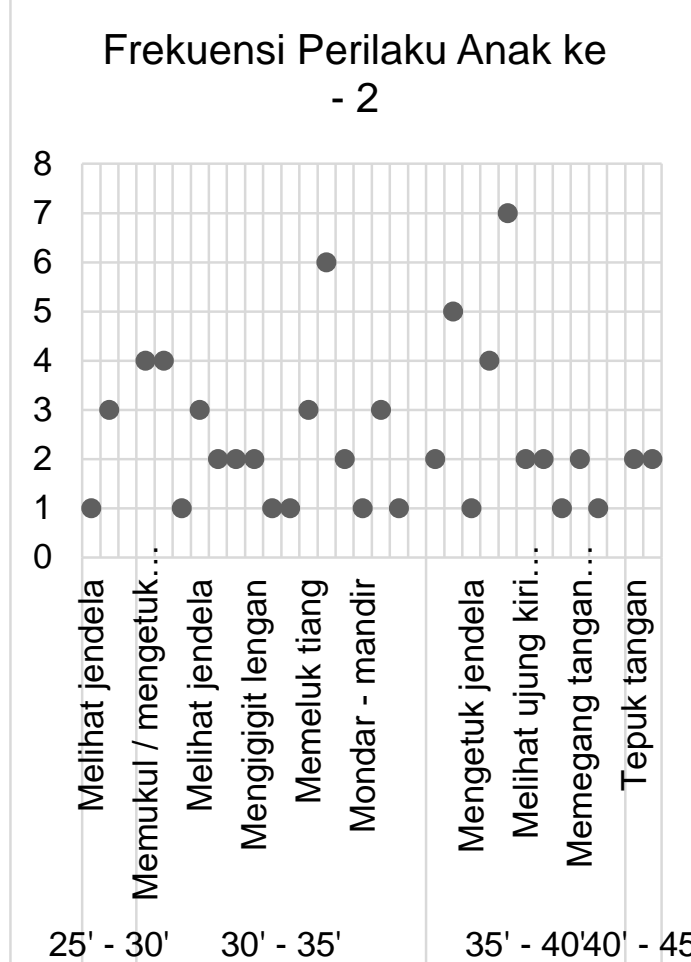

Gambar 8. Grafik frekuensi perilaku anak ke - 2 b

(Sumber: Kharista, 2018)

Frekuensi perilaku anak ke - 2 paling tinggi adalah melihat jendela sejumlah 11 kali pada periode $10-15$ menit. Interaksi dengan elemen interior paling banyak adalah melihat pintu sejumlah 43 kali dalam total waktu 45 menit. Sementara, jenis perilaku paling banyak dilakukan pada periode 30 - 35 menit yaitu sejumlah 15 jenis. Jenis perilaku paling sedikit dilakukan pada periode $25-30$ menit dan periode 40 -45 menit yaitu sejumlah 2 jenis.

3. Analisis tatar perilaku anak ke - 3 setiap periode (0 - 25 menit) ketika proses terapi dijelaskan pada Gambar 9 dan periode (25 - 45 menit) dijelaskan pada Gambar 10. Frekuensi Perilaku Anak ke
-3

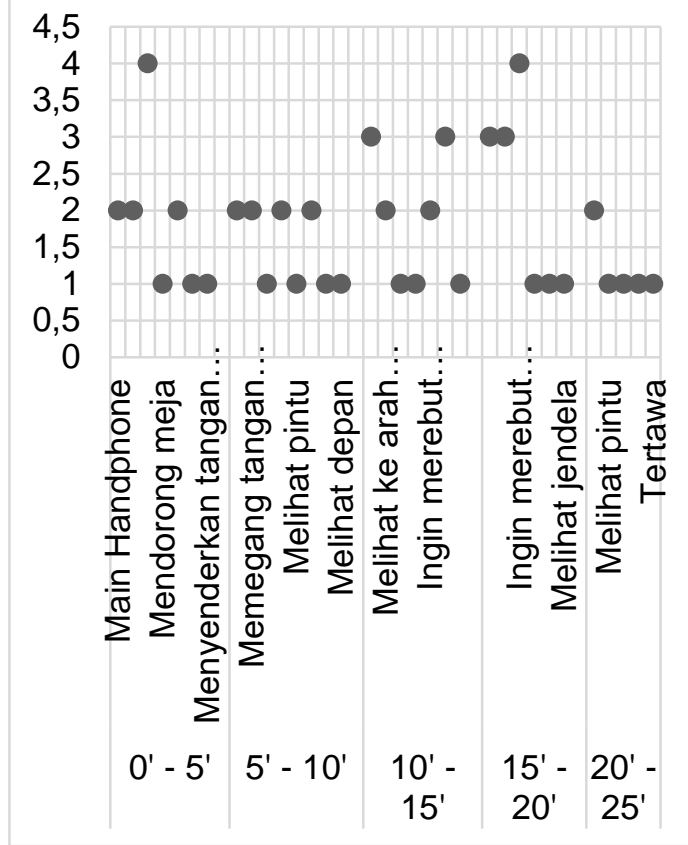

Gambar 9. Grafik frekuensi perilaku anak ke - 3 a

(Sumber: Kharista, 2018)

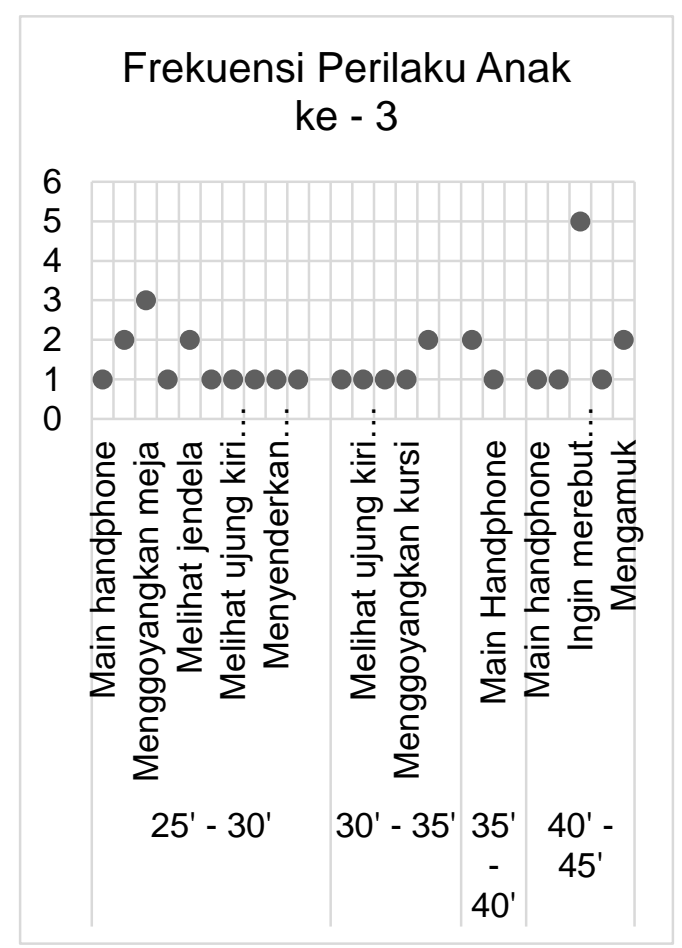

Gambar 9. Grafik frekuensi perilaku anak ke - 3 b

(Sumber: Kharista, 2018)

Tesa Arsitektur Volume 18| Nomor 1 | 2020 
Frekuensi perilaku anak ke - 3 paling tinggi adalah ingin merebut telepon genggam sejumlah 5 kali pada periode 40 - 45 menit. Interaksi dengan elemen interior paling banyak adalah melihat pintu sejumlah 11 kali dalam total waktu 45 menit. Sementara, jenis perilaku paling banyak dilakukan pada periode 25 - 30 menit yaitu sejumlah 10 jenis. Jenis perilaku paling sedikit dilakukan pada periode 35 - 40 menit yaitu sejumlah 2 jenis.

4. Analisis tatar perilaku anak ke - 4 setiap periode (0 - 10 menit) ketika proses terapi dijelaskan pada Gambar 10 dan periode (10 - 30 menit) dijelaskan pada Gambar 11.

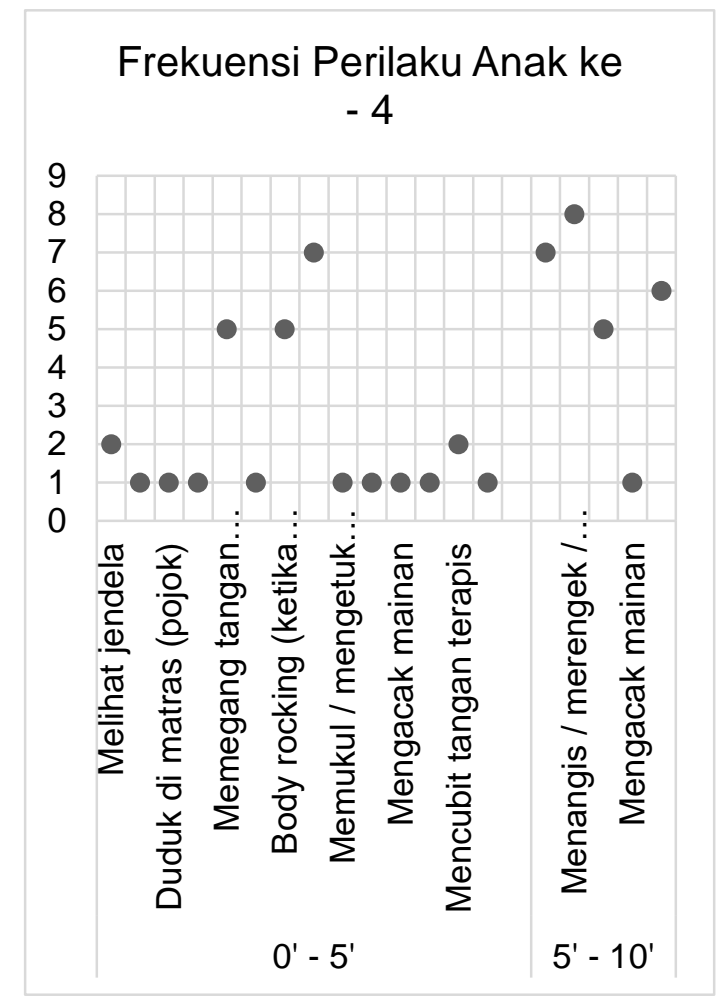

Gambar 10. Grafik frekuensi perilaku anak ke - 4 a

(Sumber: Kharista, 2018)

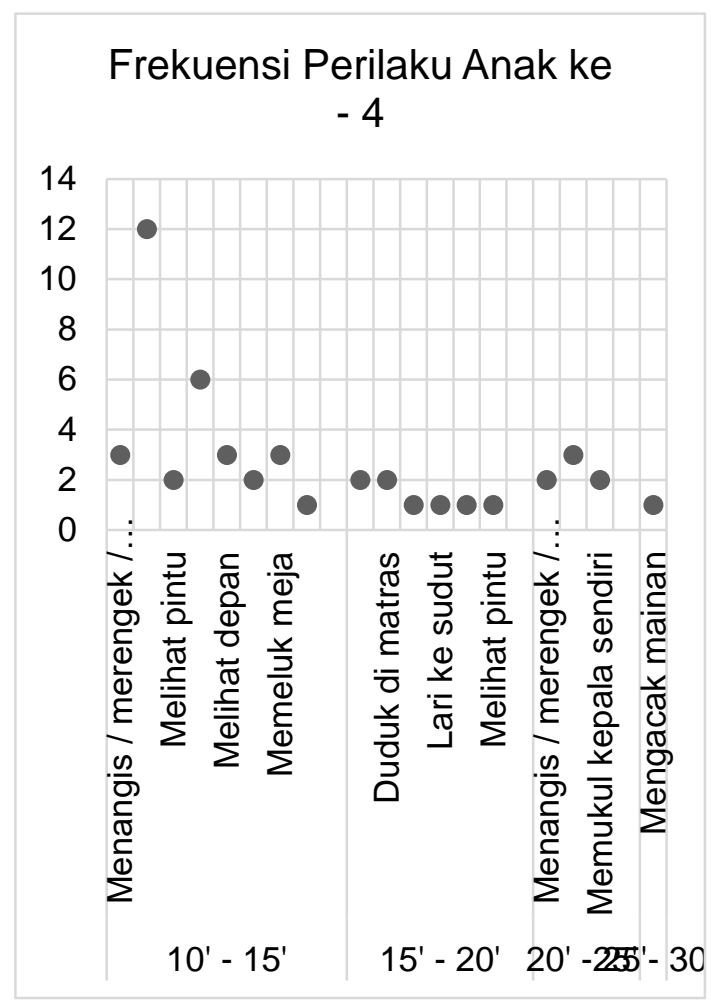

Gambar 11. Grafik frekuensi perilaku anak ke - 4 b

(Sumber: Kharista, 2018)

Frekuensi perilaku anak ke - 4 paling tinggi adalah memukul meja sejumlah 12 kali pada periode 10 - 15 menit. Interaksi dengan elemen interior paling banyak adalah melihat jam sejumlah 6 kali dalam total waktu 45 menit. Sementara, jenis perilaku paling banyak dilakukan pada periode $0-5$ menit yaitu sejumlah 14 jenis. Jenis perilaku paling sedikit dilakukan pada periode 25 - 30 menit yaitu sejumlah 1 jenis.

5. Analisis tatar perilaku anak ke - 5 setiap periode (0 - 10 menit) ketika proses terapi dijelaskan pada Gambar 12 dan periode (10 - 30 menit) dijelaskan pada Gambar 13. 


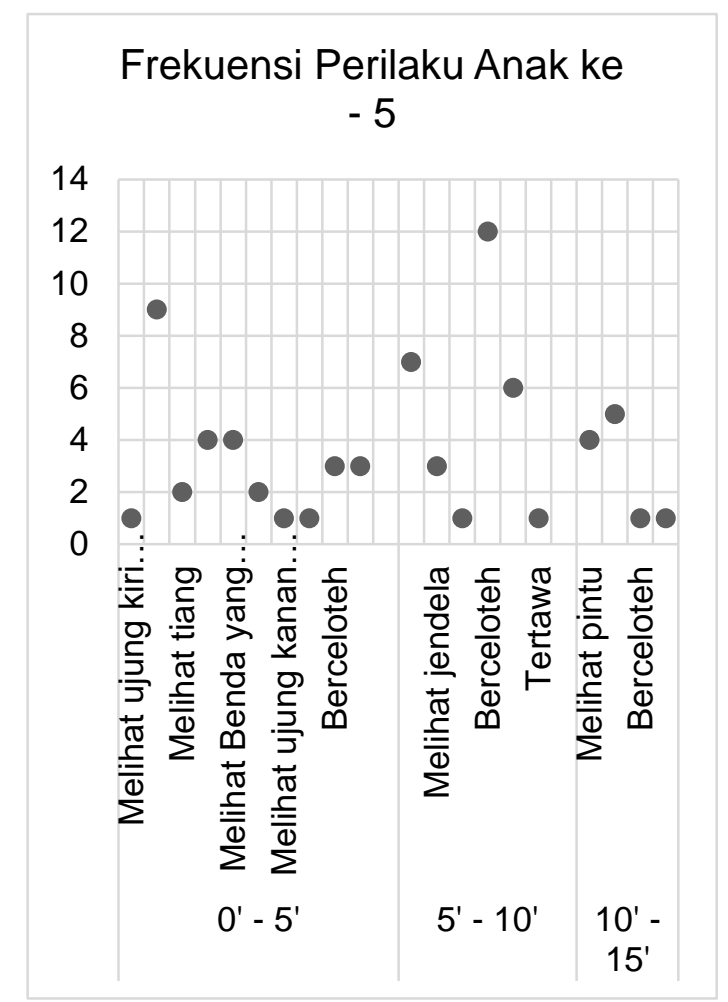

Gambar 12. Grafik frekuensi perilaku anak ke -5 a

(Sumber: Kharista, 2018)



Gambar 13. Grafik frekuensi perilaku anak ke -5 a

(Sumber: Kharista, 2018)
Frekuensi perilaku anak ke - 5 paling tinggi adalah berceloteh sejumlah 9 kali pada periode 5 - 10 menit. Interaksi dengan elemen interior paling banyak adalah melihat pintu sejumlah 30 kali dalam total waktu 25 menit. Sementara, jenis perilaku paling banyak dilakukan pada periode 15 20 menit yaitu sejumlah 13 jenis. Jenis perilaku paling sedikit dilakukan pada periode 10 - 15 menit yaitu sejumlah 4 jenis.

6. Analisis tatar perilaku anak ke - 6 setiap periode (0 - 15 menit) ketika proses terapi dijelaskan pada Gambar 14 dan periode (15 - 35 menit) dijelaskan pada Gambar 15.



Gambar 14. Grafik frekuensi perilaku anak ke -6 a

(Sumber: Kharista, 2018) 


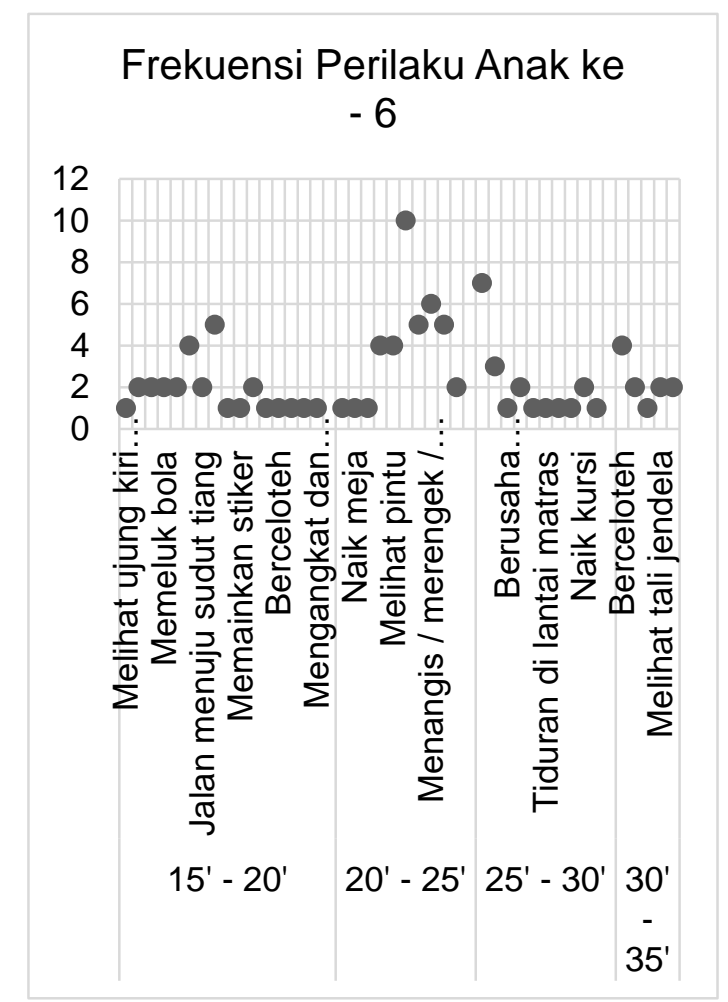

Gambar 15. Grafik frekuensi perilaku anak ke -6 b

(Sumber: Kharista, 2018)

Frekuensi perilaku anak ke - 6 paling tinggi adalah melihat jam sejumlah 10 kali pada periode 20 - 25 menit. Interaksi dengan elemen interior paling banyak adalah melihat jam sejumlah 26 kali dalam total waktu 35 menit. Sementara, jenis perilaku paling banyak dilakukan pada periode 15 - 20 menit yaitu sejumlah 16 jenis. Jenis perilaku paling sedikit dilakukan pada periode 30 - 35 menit yaitu sejumlah 5 jenis.

7. Analisis tatar perilaku anak ke - 7 setiap periode (0 - 15 menit) ketika proses terapi dijelaskan pada Gambar 16 dan periode (15 - 35 menit) dijelaskan pada Gambar 17.

\section{Frekuensi Perilaku Anak ke $-7$}

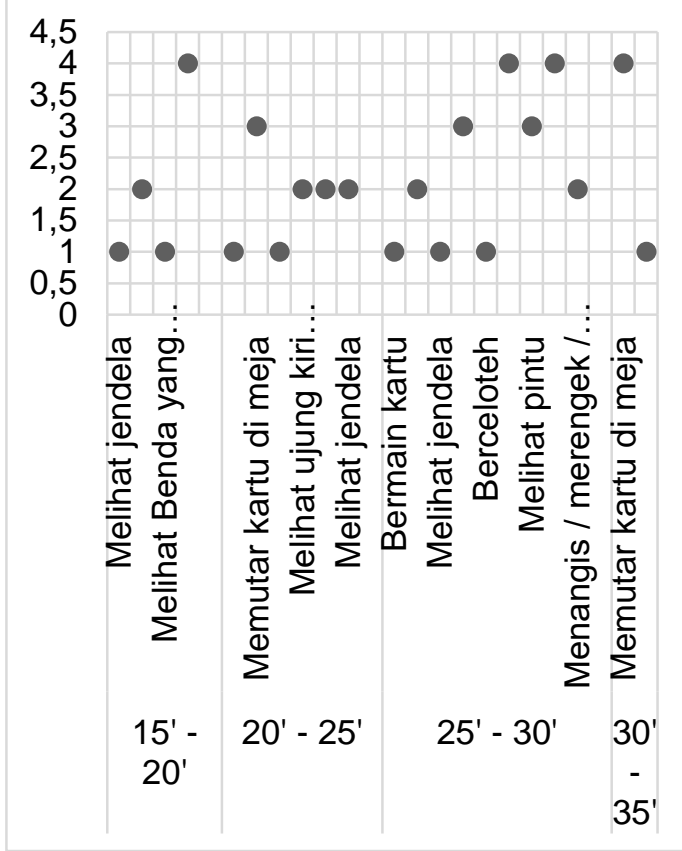

Gambar 16. Grafik frekuensi perilaku anak ke - 7 a

(Sumber: Kharista, 2018)



Gambar 17. Grafik frekuensi perilaku anak ke $-7 \mathrm{~b}$

(Sumber: Kharista, 2018)

Tesa Arsitektur Volume 18| Nomor 1 | 2020 
Frekuensi perilaku anak ke - 7 paling tinggi adalah melihat jam sejumlah 9 kali pada periode 10 - 15 menit. Interaksi dengan elemen interior paling banyak adalah melihat jam sejumlah 29 kali dalam total waktu 35 menit. Sementara, jenis perilaku paling banyak dilakukan pada periode 25 - 30 menit yaitu sejumlah 9 jenis. Jenis perilaku paling sedikit dilakukan pada periode 30 - 35 menit yaitu sejumlah 2 jenis

8. Analisis tatar perilaku anak ke - 8 setiap periode (0 - 30 menit) ketika proses terapi dijelaskan pada Gambar 18.

Frekuensi Perilaku Anak ke - 8

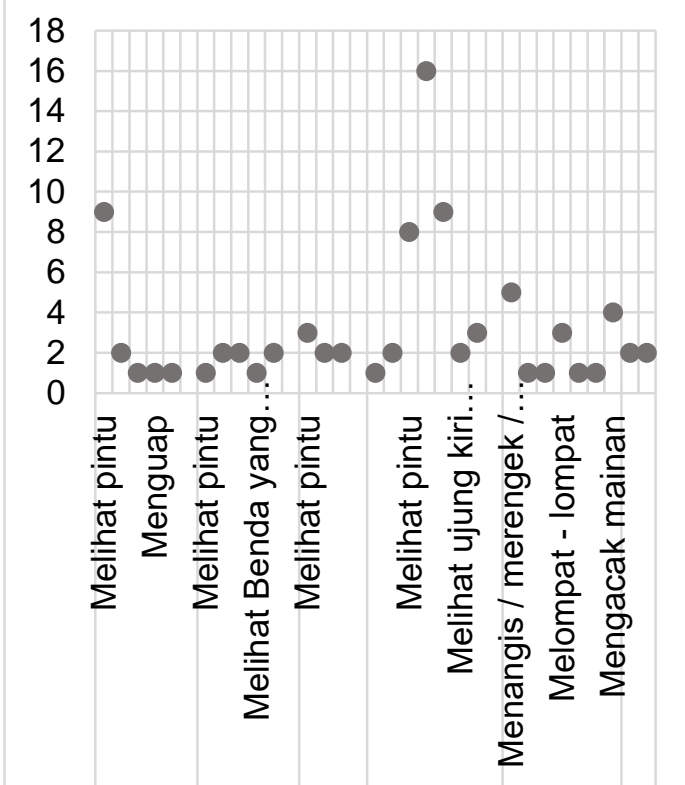

$0^{\prime}-5^{\prime} 5^{\prime}-100^{\prime}-15{ }^{\prime} 5-2020^{\prime}-25^{\prime}-30$

Gambar 18. Grafik frekuensi perilaku anak ke -8

(Sumber: Kharista, 2018)

Frekuensi perilaku anak ke - 8 paling tinggi adalah menangis sejumlah 16 kali pada periode 15 - 20 menit. Interaksi dengan elemen interior paling banyak adalah melihat pintu sejumlah 22 kali dalam total waktu 30 menit. Sementara, jenis perilaku paling banyak dilakukan pada periode 15 - 20 menit dan periode 20 - 25 menit yaitu sejumlah 7 jenis. Jenis perilaku paling sedikit dilakukan pada periode 25 30 menit yaitu sejumlah 2 jenis.

\section{Signifikansi Tatar Perilaku Anak}

Signifikansi dilakukan dengan cara uji t satu arah / one tail (terdapat perbedaan jumlah perilaku anak ketika bersama terapis dan ketika sendirian) dengan menyamakan periode yaitu selama 5 menit. Uji t mengatakan bahwa terdapat perbedaan yang signifikan antara jumlah perilaku 8 anak ketika bersama terapis dan ketika sendirian dengan $P$ value $=0.045(<$ 0.05). Sementara rata-rata jumlah perilaku ketika bersama terapis $=23.75$ dan sendirian $=33$, hal ini menunjukkan bahwa perilaku anak ketika sendirian meningkat dibandingkan ketika bersama terapis. Dapat dilihat pada tabel 1.

Tabel 1. Signifikansi uji t

\begin{tabular}{|c|c|c|}
\hline & $\begin{array}{c}\text { Bersama } \\
\text { terapis }\end{array}$ & Sendirian \\
\hline Mean & 23.75 & 33 \\
\hline Variance & $\begin{array}{r}122.78571 \\
43\end{array}$ & $\begin{array}{r}105.71428 \\
57\end{array}$ \\
\hline $\begin{array}{l}\text { Observatio } \\
\text { ns }\end{array}$ & 8 & 8 \\
\hline $\begin{array}{l}\text { Pearson } \\
\text { Correlation }\end{array}$ & $\begin{array}{r}0.2257011 \\
15\end{array}$ & \\
\hline $\begin{array}{l}\text { Hypothesiz } \\
\text { ed Mean } \\
\text { Difference }\end{array}$ & 0 & \\
\hline$d f$ & 7 & \\
\hline t Stat & $\begin{array}{r}- \\
1.9661311 \\
35\end{array}$ & \\
\hline $\begin{array}{l}P(T<=t) \\
\text { one-tail }\end{array}$ & $\begin{array}{r}0.0450014 \\
47\end{array}$ & \\
\hline $\begin{array}{l}\text { t Critical } \\
\text { one-tail }\end{array}$ & $\begin{array}{r}1.8945786 \\
05\end{array}$ & \\
\hline
\end{tabular}

Uji anova faktor tunggal (single factor) dilakukan untuk mengetahui apakah ada perbedaan pola (baik ketika bersama terapis maupun sendirian) yang signifikan antara 8 anak. Uji anova mengatakan bahwa tidak ada perbedaan pola yang signifikan antara 8 anak dengan $\mathrm{P}$ value $=$

Tesa Arsitektur Volume 18| Nomor 1 | 2020 
0.413 (>0.05), hal ini berarti kedelapan anak memiliki pola yang sama (baik ketika bersama terapis maupun sendirian). Dapat dilihat pada tabel 2.

Tabel 2. Signifikansi uji annova

\begin{tabular}{lrrr}
\hline $\begin{array}{l}\text { Source of } \\
\text { Variation }\end{array}$ & SS & df & P-value \\
\hline $\begin{array}{l}\text { Between } \\
\text { Groups } \\
\text { Within } \\
\text { Groups }\end{array}$ & 979.75 & 7 & 0.41395 \\
& 962 & 8 & \\
Total & 1941.75 & 15 \\
\hline \multicolumn{4}{c}{ (Sumber: Kharista, 2018) }
\end{tabular}

\section{Analisis}

Delapan anak rata-rata melalui proses terapi selama 36 menit, tergantung dari materi terapi dan kondisi anak tersebut. Setiap anak memiliki perilaku yang berbeda-beda tetapi memiliki beberapa perilaku yang serupa. Beberapa diantaranya adalah pada periode 5 menit pertama, anak sama-sama melihat pintu, jendela dan jam. Pada periode 10 menit pertama anak akan melihat benda apa yang dipegang terapis karena sudah masuk ke materi terapi.

Sebelum proses terapi berlangsung, anak akan melakukan fase pengenalan lingkungan / adaptasi dengan cara mengelilingi dan melihat sekeliling ruangan tersebut dan memperhatikan secara berulang kali objek yang dianggap asing baginya, hingga akhirnya mulai mengidentifikasinya dengan mendekati objek tersebut, melihat, memegang dan beberapa akan menggosok (menepuk). Ini menunjukkan keingintahuan apakah ruang / objek tersebut membuat anak nyaman / tidak. Anak memiliki perilaku yang sama yaitu mudah terdistraksi dengan elemen interior (jendela, jam, pintu) ketika proses terapi berlangsung sehingga terapi tidak berjalan maksimal, sebaliknya ketika sendirian ia tertarik / terdistraksi terhadap elemen interior tersebut.

TERAKREDITASI : 36/E/KPT/2019
Oleh karena itu, sebagai desainer interior harus memahami perilaku pengguna ruang di dalamnya. Dalam hal ini, ruang terapi untuk anak autis harus disesuaikan dengan perilakunya. Tidak dapat disamakan dengan ruang untuk umum lainnya agar dapat memaksimalkan aktifitas yang dilakukan di dalam ruang. Sebagai contoh perilaku seringnya melihat / terdistraksi visual. Ruang dapat dibuat dengan meminimalisir penempatan objek / benda di dalam ruang. Perilaku sering memukul dan memegang, maka ruang dapat dibuat menggunakan material yang aman dari kecelakaan (hindari sudut tajam dan kasar). Akan tetapi tetap tidak semua perilaku dapat diatasi dengan solusi desain interior, seperti perilaku tertawa, mendengkur dan berceloteh.

\section{PENUTUP}

\section{Kesimpulan}

Memberdayakan desain interior untuk menuju pembangunan yang lebih baik dapat dilakukan dari hal kecil seperti memperhatikan sarana pendidikan bagi anak autis. Desainer interior dapat berperan dalam membangun sarana pendidikan yang sesuai dengan tatar perilaku anak autis. Setelah mengetahui perilaku anak di dalam ruang, maka desainer interior dapat mendesain sarana pendidikan tersebut sesuai kebutuhan dan akan maksimal.

\section{Saran}

Penelitian selanjutnya dapat dilakukan dengan mengamati perilaku pada ruang yang memiliki elemen interior yang berbeda. Selain itu, akan lebih baik apabila memiliki responden yang jumlahnya lebih banyak karena dapat menghasilkan data yang lebih signifikan.

\section{Ucapan Terima Kasih}

Penulis mengucapkan terima kasih kepada Dr. Imam Santosa, M.Sn, Dr. Andar Bagus Sriwarno, M.Sn, dan Dr. Indun Lestari Setyono, M.Psi, selaku dosen

Tesa Arsitektur Volume 18| Nomor 1 | 2020 
pembimbing yang telah meluangkan banyak waktu, tenaga, dan pikiran di dalam memberikan pengarahan dan semangat dalam penulisan jurnal ini.

\section{DAFTAR PUSTAKA}

Ching, F. D.K. 1996. Ilustrasi Desain Interior. Jakarta: Airlangga.

Ghaziani, R. 2008. "Children's voices: Raised issues for school design." International Journal of Cocreation in Design and the Arts. 4 (4) 225 - 236.

Handojo, Y. 2003. Autisme: petunjuk praktis dan pedoman materi untuk mengajar anak normal, autis dan perilaku lain. Jakarta: PT. Bhuana IImu Populer.

Haryadi, B. S. 1996. Arsitektur Lingkungan dan Perilaku, Suatu Pengantar ke Teori,

Metodologi dan Aplikasi. Direktorat Jendral Pendidikan. Yogyakarta.

Jenkins, J. 2009. Designing learning spaces for children on the autism spectrum. University of Birmingham.

Laurens, J. M. 2004. Arsitektur dan Perilaku Manusia. Jakarta: PT Grasindo. 131.

Maulana, M. .2007. Mendidik anak autis dan gangguan mental lain menuju anak cerdas dan sehat. Yogyakarta: Kata Hati.

Peeters, T. 2004. Autisme. Jakarta: Dian Rakyat.

Pile, J. .2000. A history of interior design. 3rd ed. London: Laurence King.

Sommer, R., Sommer, B. (2001): A practical guide to behavioral research. New York: Oxford University Press.

Wildes, P, A. J. .2005. "Sensory stimulation and autistic children. Implications". 6(4), 5.https://www.informedesign.org/_new s/ apr_v06r-pr.pdf (diakses pada 8 Agustus 2018). 